\title{
Studi Crossectional Hubungan Sikap, Dukungan Keluarga dan Pengetahuan dengan Perilaku Higienis Remaja Saat Menstruasi di SMA Kartika X1V-1 Banda Aceh
}

\author{
Cross Sectional Study of Relationship between Attitudes, Family and \\ Knowledge Support with Adolescent Hygiene Behavior during Menstruation at \\ Kartika X1V-1 High School Banda Aceh
}

\author{
Nuzulul Rahmi ${ }^{* 1}$, Asmaul Husna ${ }^{2}$ Fauziah Andika $^{3}$ \\ ${ }^{1}$ Program Studi D-IV Kebidanan, Fakultas Ilmu Kesehatan, Universitas Ubudiyah Indonesia, Banda Aceh Indonesia \\ ${ }^{2}$ Program Studi D-III Kebidanan Fakultas Ilmu Kesehatan, Universitas Ubudiyah Indonesia, Banda Aceh Indonesia \\ ${ }^{3}$ Program Studi Ilmu Kesehatan Masyarakat, Fakultas Ilmu Kesehatan, Universitas Ubudiyah Indonesia, Banda Aceh \\ Indonesia
}

*Korespondensi Penulis: nuzulul_r@uui.ac.id

\begin{abstract}
Abstrak
Menstruasi adalah perdarahan periodik dari uterus yang dimulai sekitar 14 hari setelah ovulasi secara berkala akibat terlepasnya lapisan endometrium uterus. Remaja putrid perlu menjaga kebersihan alat reproduksi pada saat menstruasi agar terhindar dari penyakit infeksi yang dapat merugikan dirinya sendiri atau orang lain. Rendahnya perilaku higienis saat menstruasi dapat menimbulkan beberapa penyakit berupa infeksi alat reproduksi seperti vaginitis, trichomoniasis, pedikuloris dan keputihan. Penelitian ini bersifat analitik dengan pendekatan cross sectional, populasi yaitu seluruh siswi SMA Kartika XIV-1 sejumlah 51 orang, Tehnik pengambilan sampel dalam penelitian ini dilakukan secara Total Sampling dengan menetapkan semua populasi siswi sebanyak 51 orang sebagai sampel, pengumpulan data dilakukan dengan menggunakan kuesioner. Tehnik analisis data menggunakan chi-square, Ha ditolak jika $p$ value $\geq 0,05$ dan Ha diterima jika $p$ value $\leq 0,05$. Penelitian ini dilakukan pada tanggal 02-03 Juni 2016. Hasil penelitian menunjukan bahwa dari hasil uji statistik diperoleh ada hubungan pengetahuan dengan perilaku higienis remaja saat menstruasi $p$ value $(0,041)$, ada hubungan dukungan keluarga dengan perilaku higienis remaja saat menstruasi $\mathrm{p}$ value $(0,001)$, ada hubungan sikap dengan perilaku higienis remaja saat menstruasi $p$ value $(0,006)$. Berdasarkan hasil penelitian ini di dapatkan dari analisis statistik $p$ value $\leq 0,05$ yaitu ada hubungan pengetahuan, dukungan keluarga dan sikap dengan perilaku higienis remaja saat menstruasi di SMA Kartika XIV-1 Banda Aceh. Diharapkan kepada Kepala sekolah beserta Guru dapat memberikan informasi kepada remaja putrid mengenai perilaku higienis remaja saat menstruasi.
\end{abstract}

Kata Kunci : Perilaku higienis remaja saat menstruasi, pengetahuan, dukungan keluarga, sikap. 


\begin{abstract}
Menstruation is periodic bleeding from the uterus which starts around 14 days after ovulation periodically due to the release of the uterine endometrial lining. Female teenagers need to maintain the cleanliness of their reproductive organs during menstruation to avoid infectious diseases that can harm themselves or others. The low hygienic behavior during menstruation can cause several diseases such as reproductive infections such as vaginitis, trichomoniasis, pediculoris and vaginal discharge. This study is analytical with a cross sectional approach, the population is all high school students Kartika XIV-1 numbering 51 people, the sampling technique in this study was carried out in total sampling by setting all student populations as many as 51 people as samples, data collection was done using a questionnaire. The data analysis technique used chi-square, Ha was rejected if $p$ value $\geq 0.05$ and Ha were accepted if $p$ value $\leq 0.05$. This study was conducted on June 2 to 3 2016. The results showed that the results of statistical tests showed that there was a relationship between knowledge with hygiene behavior of adolescents during menstruation $p$ value (0.041), there was a relationship between family support and adolescent hygiene behavior during menstruation $p$ value (0.001), there is a relationship between attitude and hygiene behavior of adolescents during menstruation p value (0.006). Based on the results of this study, it was obtained from the statistical analysis $p$ value 5 0.05, that is, there was a relationship between knowledge, family support and attitudes with adolescent hygiene behavior during menstruation at SMA Kartika XIV-1 Banda Aceh. It is expected that the principal and the teacher can provide information to young girls about the hygiene behavior of adolescents during menstruation.
\end{abstract}

Keywords: Youth hygiene behavior during menstruation, knowledge, family support, attitude.

\title{
PENDAHULUAN
}

Perilaku higienis remaja pada saat menstruasi masih rendah, diperlihatkan oleh sebuah penelitian Widyantoro (Mohammad, 2009) mengenai higienitas menstruasi pada perempuan pengunjung rumah sakit di Subang dan Tangerang mengungkapkan bahwa sebagian besar 77,5\% di Tangerang dan 68,3\% di Subang) mempunyai status higienitas menstruasi yang buruk. Dalam hal higienitas individu, masih terdapat responden yang Salah dalam mencuci alat kelaminnya yaitu dari arah belakang ke depan 20,1\% pada hari biasa dan 19,8 \% pada saat menstruasi). Penelitian ini memperlihatkan bahwa responden di Subang memperlihatkan higienitas menstruasi cenderung lebih tinggi dibanding responden di Tangerang. Pemahaman seseorang terhadap sistem maupun fungsi reproduksinya sangatlah penting. Seseorang yang tidak memiliki pengetahuan tentang kesehatan reproduksi yang cukup, akan cenderung mengabaikan kesehatan reproduksinya dan pada akhirnya ia akan melakukan tindakan yang membahayakan bagi dirinya sendiri. Pengetahuan tentang kesehatan reproduksi merupakan faktor penting dalam menentukan perilaku higienis perempuan pada saat menstruasi. Rendahnya pengetahuan tentang kesehatan reproduki akan memungkinkan perempuan tidak 
berperilaku higienis pada saat menstruasi yang dapat membahayakan kesehatan reproduksinya sendiri (BKKBN, 2012).

Berdasarkan hasil studi pendahuluan yang dilakukan di SMA KARTIKA XIV-1 Banda Aceh 12 januari 2016 didapatkan informasi jumlah seluruh siswi berjumlah 51 Orang, terdiri dari kelas X sejumlah 18 orang, kelas XI sejumlah 19 orang, kelas XII sejumlah 14 orang. Dengan melakukan wawancara serta membagikan kuesioner kepada 12 orang siswi SMA kartika di dapatkan 5 orang mengetahui kesehatan reproduksi dan perilaku higienis remaja saat menstruasi sedangkan 7 orang lagi tidak mengerti dikarenakan pengetahuan dan informasi yang di dapatkan remaja masih kurang dari perilaku higienis remaja saat mengalami menstruasi.

\section{METODE PENELITIAN}

Jenis penelitian ini adalah bersifat deskriptif korelasional dengan desain penelitian cross sectional, dimana variabel independen dan variabel dependen diteliti secara bersamaan pada saat penelitian dilakukan. Penelitian dilakukan bertujuan untuk mengetahui Faktor-Faktor yang berhubungan dengan Perilaku Higienis Remaja saat Menstruasi di SMA Kartika XIV-1 Banda Aceh Tahun 2016. Populasi dalam penelitian ini adalah keseluruhan objek penelitian yang diteliti, dimana penelitian yang diteliti dalam penelitian ini adalah seluruh siswi SMA Kartika X1V-1 sejumlah 51 orang. Pengambilan sampel dalam penelitian ini dilakukan secara total sampling yaitu dengan cara menetapkan semua populasi siswi sebanyak 51 orang sebagai keseluruhan sampel yang akan diteliti. Penelitian ini dilaksanakan di SMA Kartika X1V-1 Banda Aceh Tahun 2016 dilaksanakan pada tanggal 02-03 Juni 2016. Adapun instrument penelitian yang digunakan dalam penelitian ini adalah kuesioner multiple choise. Sebanyak 35 soal,dimana 15 soal untuk variabel pengetahuan, 5 soal untuk variabel dukungan keluarga, 5 soal untuk variabel sikap dan 10 soal untuk variabel perilaku. Tehnik analisis data menggunakan chi-square, Ha ditolak jika $p$ value $\geq 0,05$ dan Ha diterima jika $p$ value $\leq 0,05$.

\section{HASIL DAN PEMBAHASAN}

\section{Hubungan Pengetahuan Dengan Perilaku Higienis Remaja Wanita Saat Menstruasi}

Berdasarkan hasil penelitian yang telah dilakukan oleh peneliti menunjukkan bahwatingkat pengetahuan yang kurang baik dengan perilaku higienis remaja yang negatif 
saat menstruasi sebesar 55,2\% sedangkan Remaja dengan tingkat pengetahuan yang baik dengan perilaku higienis remaja yang negatif saat menstruasi sebesar 22,7\%. Maka dapat disimpulkan bahwa remaja dengan Tingkat pengetahuan yang kurang baik dengan perilaku higienis remaja yang negatif saat menstruasi lebih banyak dibandingkan dengan remaja yang tingkat pengetahuannya baik saat perilaku higienis remaja saat menstruasi. Hasil analisis statistik menggunakan uji chi-square didapatkan p-value $=0,041$. Sehingga dapat disimpulkan bahwa $\mathrm{p}<0,05$ yang artinya Ha diterima atau terdapat Hubungan Pengetahuan Dengan Perilaku Higienis Remaja Saat Menstruasi.

Menurut Penelitian Wahyulisasni (2010) yang dilakukan di SMP Pembangunan Universitas Negeri Padang (UNP) menunjukkan tingkat pengetahuan siswi tentang menstruasi. Siswi dengan pengetahuan tinggi tentang menstruasi sebanyak 43,4\%, siswi dengan pengetahuan sedang sebanyak $51,3 \%$, dan sisa dengan pengetahuan rendah sebanyak 5,3\%.Setelah dilakukan uji statistik dengan menggunakan chi-square maka diperoleh nilai $p$-value0,000 $(<0,05)$, dengan demikian dapat ditarik kesimpulan bahwa ada hubungan Pengetahuan dengan Perilaku higienis Remaja saat menstruasi. Menurut Penelitian Nurma (2011) yang dilakukan di SMA 2 Semarang menunjukkan tingkat pengetahuan siswi tentang menstruasi. dengan pengetahuan tinggi saat menstruasi sebanyak 66,6\%, siswi dengan pengetahuan sedang sebanyak 29,4\%, dan sisa dengan pengetahuan rendah sebanyak $100 \%$.Setelah dilakukan uji statistik dengan menggunakan chi-square maka diperoleh nilai p-value0,003 $(<0,05)$, dengan demikian dapat ditarik kesimpulan bahwa ada hubungan Pengetahuan dengan Perilaku higienis Remaja saat menstruasi. Menurut Penelitian Sri Haryati (2013) menunjukkan tingkat pengetahuan siswi saat menstruasi.dengan pengetahuan yang baik saat menstruasi sebanyak 66,5\% siswi dengan pengetahuan kurang sebanyak 59,4\%, Setelah dilakukan uji statistik dengan menggunakan chi-square maka diperoleh nilai p-value 0,001 $(<0,05)$, dengan demikian dapat ditarik kesimpulan bahwa ada hubungan Pengetahuan dengan Perilaku higienis Remaja saat menstruasi.

Pengetahuan adalah merupakan hasil dari tahu dan ini terjadi setelah orang melakukan Pengindaran terhadap objek tertentu. Penginderaan terhadap objek terjadi melalui panca indra manusia, yakni; penglihatan, pendengaran, penciuman, rasa, dan raba. Sebagian besar pengetahuan manusia diperoleh melalui mata dan telinga (Notoatmodjo, 2007 dalam Sari 2012). Pengetahuan tentang kesehatan reproduksi merupakan faktor 
penting dalam menentukan perilaku higienis perempuan pada saat menstruasi. Rendahnya pengetahuan tentang kesehatan reproduksi akan memungkinkan perempuan tidak berperilaku higienis pada saat menstruasi yang dapat membahayakan kesehatan reproduksinya sendiri (BKKBN, 2012). Menurut Asumsi peneliti, pengetahuan akan sangat berpengaruh terhadap Remaja yang mengalami perilaku higienis Remaja saat menstruasi. Seseorang yang memiliki pengetahuan baik akan semakin positif pula tentang Perilaku higienis Remaja saat menstruasi, dan sebaliknya jika Remaja memiliki pengetahuan kurang maka akan berdampak semakin negatif terhadap Perilaku Higienis Remaja saat Menstruasi.

\section{Hubungan Dukungan Keluarga Dengan Perilaku Higienis Remaja Wanita Saat Menstruasi}

Berdasarkan hasil penelitian yang telah dilakukan oleh peneliti menunjukkan bahwakeluarga yang tidak mendukung dengan perilaku higienis remaja yang negatif saat menstruasi sebesar 69,6\% sedangkan keluarga yang mendukung dengan perilaku higienis remaja yang negatif saat menstruasi sebesar 17,9\%. Maka dapat disimpulkan bahwa Remaja dengan Keluarga yang mendukung lebih banyak mengalami perilaku higienis remaja saat menstruasi yang positif dibandingkan Remaja dengan keluarga yang tidak mendukung. Hasil analisis statistik menggunakan uji chi-square didapatkan p-value = 0,001. Sehingga dapat disimpulkan bahwa $\mathrm{p}<0,05$ yang artinya Ha diterima atau terdapat Hubungan Dukungan Keluarga Dengan Perilaku Higienis Remaja Saat Menstruasi.

Berdasarkan hasil penelitian Rina (2013) menunjukkan bahwa dari 33 responden, yangmendapat dukungankeluarga sebanyak 31 orang $(93,9 \%)$ dengan perilaku Higienis remaja saat menstruasi yang mendukung. Sedangkan dari 16 responden yangtidak mendapat dukungan keluarga sebanyak 15 orang (93,8\%)perilaku higienis remaja saat menstruasi tidak Mendukung Berdasarkan Uji Chi-Square di peroleh nilai $\mathrm{P}=0,000$ jika $\mathrm{P}-$ Value $\leq \alpha=0,05$.dengan demikian dapat ditarik kesimpulan bahwa ada hubungan antara Dukungan keluarga dengan perilaku higienis Remaja saat menstruasi. Berdasarkan hasil penelitian Ratih (2010) menunjukkan bahwa dengan dukungankeluarga yang mendukung sebanyak 30 orang $(83,9 \%)$ dengan perilaku Higienis remaja saat menstruasi Sedangkan dari 16 responden yangtidak mendapat dukungan keluarga sebanyak 13 orang (76,8\%)perilaku higienis remaja saat menstruasi tidak Mendukung Berdasarkan Uji Chi- 
Square di peroleh nilai $\mathrm{P}=0,000$ jika $\mathrm{P}-$ Value $\leq \alpha=0,05$.dengan demikian dapat ditarik kesimpulan bahwa ada hubungan antara Dukungan keluarga dengan perilaku higienis remaja saat menstruasi.

Berdasarkan hasil penelitian yang dilakukan oleh Santi (2012) diperoleh bahwa dari 90 responden,70,5\% Remaja dengan dukungan keluarga yang mendukung dan 59,8\% remaja dengan dukungan keluarga yang tidak mendukung terhadap perilaku higienis remaja saat menstruasi. Dari Hasil analisa statistik dengan menggunakan uji chi square menunjukkan ada hubungan antara dukungan keluarga dengan perilaku higienis remaja saat menstruasi dengan nilai $\mathrm{p}$ value $0,000 \quad(\mathrm{P}<0,05)$ dengan demikian dapat ditarik kesimpulan bahwa ada hubungan antara Dukungan keluarga dengan perilaku higienis Remaja saat menstruasi.

Dukungan keluarga didefinisikan Zainudin (2010) yaitu informasi verbal, sasaran, bantuan yang nyata atau tingkah laku yang diberikan oleh orang-orang yang akrab dengan subjek didalam lingkungan sosialnya atau yang berupa kehadiran dan hal yang dapat memberikan keuntungan emosional atau pengaruh pada tingkah laku penerimaannya. Dalam hal ini orang yang merasa memperoleh dukungan sosial, secara emosional merasa lega diperhatikan, mendapat saran atau kesan yang menyenangkan pada dirinya. Menurut Ratih (2008) dukungan keluarga pada Remaja dalam perilaku higienis remaja saat menstruasi adalah sebagai adanyainformasi, perhatian, penghargaan atau menolong dengan sikap menerima kondisinya, dukungan keluarga tersebut diperoleh dari individu maupun kelompok. Menurut Asumsi peneliti dukungan keluarga sangat berpengaruh terhadap perilaku Higiene Remaja saat menstruasi, karena dukungan keluarga dapat berupa dukungan emosional, materi dan informasi dimana remaja membutuhakan semua hal-hal tersebut.Sehingga semakin dukungan keluarga mendukung maka semakin positif pula perilaku higienis remaja saat menstruasi dan sebaliknya jika dukungan keluarga tidak mendukung maka semakin negatif pula perilaku Higienis remaja saat menstruasi.

\section{Hubungan Sikap Dengan Perilaku Higienis Remaja Wanita Saat Menstruasi}

Berdasarkan hasil penelitian yang telah dilakukan oleh peneliti menunjukkan bahwa sikap remaja yang positif dengan perilaku higienis remaja saat menstruasi sebesar $58,1 \%$ sedangkan sikap remaja yang positif dengan perilaku higienis remaja saat menstruasi sebesar $15 \%$. Maka dapat disimpulkan bahwa remaja yang sikap Negatif lebih banyak 
mengalami perilaku Higienis Remaja saat menstruasi dibandingkan siswa yang bersikap positif. Hasil analisis statistik menggunakan uji chi-square didapatkan p-value $=0,006$. Sehingga dapat disimpulkan bahwa $\mathrm{p}<0,05$ yang artinya Ha diterima atau terdapat Hubungan Sikap Dengan Perilaku Higienis Remaja Saat Menstruasi.

Penelitian sri raharyu (2008) yang dilakukan di SMA bukit tinggi menunjukkan sikap siswi tentang menstruasi. Siswi dengan sikap yang tinggi mengetahui tentang menstruasi sebanyak $42,4 \%$, siswi dengan sikap sedang sebanyak $51,3 \%$, dan sisa dengan sikap rendah sebanyak 5,3\%. Responden mempunyai sikap mendukung terhadap perilaku kebersihan saat menstruasi, ini terlihat dari hasil uji chi square, dengan analisis bivariat mendapatkan nilai $\mathrm{p}=0,002$, artinya dengan nilai $\alpha=0,05$ maka nilai $\mathrm{p}$ tersebut $<$ dari $\alpha$ sehingga dapat disimpulkan bahwa sikap responden mempunyai hubungan yang signifikan terhadap perilaku kebersihan pada saat menstruasi, dengan nilai OR 3,491 berarti bahwa siswi dengan sikap mendukung akan memiliki kemungkinan 3,491 kali lebih besar melakukan perilaku kebersihan pada saat menstruasi yang baik dibandingkan dengan sikap kurang mendukung. Penelitian wahyuni ( 2010 ) dari 46 responden bersikap positif yang mengalami perilaku higienis remaja saat menstruasi sebanyak 33 orang $(71,7 \%)$ dan dari 24 responden yang bersikap negatif yang mengalami perilaku higienis remaja saat menstruasi sebanyak 11 orang $(42,3 \%)$. Hasil analisis statistic menunjukan bahwa ada hubungan antara sikap dengan perilaku higienis remaja saat menstruasi dengan P-Value = 0,006. Penelitian Ningsih ( 2014 ) dari 60 responden bersikap positif yang mengalami perilaku higienis remaja saat menstruasi sebanyak 32 orang $(69,7 \%)$ dan dari 28 responden yang bersikap negatif yang mengalami perilaku higienis remaja saat menstruasi sebanyak 15 orang (48,3\%). Hasil analisis statistik menunjukan bahwa ada hubungan antara sikap dengan perilaku higienis remaja saat menstruasi dengan P-Value $=0,000$.

Sikap adalah merupakan kesiapan atau kesediaan untuk bertindak, dan bukan merupakan pelaksanaan motif tertentu. Dalam kata lain fungsi sikap belum merupakan tindakan (reaksi terbuka) atau aktifitas, akan tetapi merupakan predisposisi perilaku (tindakan), atau reaksi tertutup (Notoatmodjo, 2010). Menurut Notoatmodjo (2010) sikap itu terdiri dari 3 komponen pokok, yaitu : (1) Kepercayaan atau keyakinan, ide, dan konsep terhadap objek, artinya bagaimana keyakinan, pendapat atau pemikiran Remaja terhadap perilaku higienis remaja saat menstruasi (2) Kehidupan emosional atau evaluasi orang terhadap objek, artinya bagaimana penilaian (terkandung didalam faktor emosi) Remaja 
terhadap perilaku higienis remaja saat menstruasi, (3) Kecenderungan untuk bertindak (tend to behave), artinya sikap adalah merupakan komponen yang mendahului tindakan atau perilaku terbuka. misalnya sikap Remaja untuk bertindak atau berperilaku terhadap perilaku higienis remaja saat menstruasi. Menurut Asumsi peneliti, sikap merupakan kesiapan seseorang dalam bertindak sehingga akan sangat berpengaruh terhadap tindakan yang dilakukan oleh seseorang. Semakin positif sikap seseorang maka akan semakin positif pula pandangan seseorang tentang perilaku higienis remaja saat menstruasi.

\section{KESIMPULAN}

Berdasarkan hasil penelitian ini di dapatkan dari analisis statistik $\mathrm{p}$ value $\leq 0,05$ yaitu ada hubungan pengetahuan, dukungan keluarga dan sikap dengan perilaku higienis remaja saat menstruasi di SMA Kartika XIV-1 Banda Aceh.

\section{SARAN}

Diharapkan kepada Kepala sekolah beserta Guru dapat memberikan informasi kepada remaja putri mengenai perilaku higienis remaja saat menstruasi dan para petugas kesehatan melakukan penyuluhan kepada remaja untuk menginformasikan perilaku higienis remaja saat mesntruasi.

\section{DAFTAR PUSTAKA}

BKKBN. (2012). Buku pedoman perilaku Higienis saat Menstruasi. Edisi kedua,Jakarta: ECG.

Depkes RI, (2004) . Higienis Remaja.Departemen Kesehatan Republik Indonesia :

Jakarta.

(2010). Problem Kesehatan Reproduksi. departemen Kesehatan Republik Indonesia, Jakarta.

Dwi. (2010). 2 cara pengukuran pengetahuan.http://www.academia.go.id (dikutip 28 juni 2011)

Dianawati, A. (2006). Pendidikan kesproe Untuk Remaja. Jakarta: Penerbit PT.Kawan

Data SKRRI. (2009). Presentasi Pengetahuan Remaja Terhadap Kesehatan Reproduksi. http:// www.academia.go.id ( dikutip 3 Maret 2016)

Dr.Athif, Lammadhah. (2006). Menstruasi Tanpa Rasa Sakit. Yogyakarta: Buku islam Utama.

Marlyn. (2008). Pengaruh dukungan keluarga terhadap perubahan respon social emosional.Skripsi Program Studi Ilmu Keperawatan Fakultas Kedokteran Universitas Airlangga Surabaya 
Rani. (2009). Kamus besar Bahasa Indonesia.jakarta : salemba medika

Ratna. (2014). Kebersihan alat genetalia, blogspot.com/2010/12/d.pengetahuan (22 Juni 2012)

Suryati, B. (2012). Perilaku Kebersihan remaja saat menstruasi. Jakarta : Jurnal Health Quality Volume 3 no 1 November 2012

WHO. 2012. Kesehatan Reproduksi Remaja. Dikutip dari Majalah He wold edisi Maret 2010, halaman 152-153 